The Voluntary Food Intake of Pigs

Occasional Publication No. 13-British Society of Animal Production 1989

edited by J. M. Forbes, M. A. Varley and T. L. J. Lawrence

\title{
VOLUNTARY FOOD INTAKE OF PIGS OF HIGH GENETIC POTENTIAL FED PELLETS TO APPETITE: EFFECTS OF SEX AND DIETARY PROTEIN CONTENT
}

\section{J. J. MCCRACKEN}

Food and Agricultural Chemistry Research Division, Department of Agriculture, Newforge Lane, Belfast BT9 5PX

and

\section{R. I. STOCKDALE}

Northern Ireland Pig Testing Station, Department of Agriculture, 14 Kirby's Lane, Antrim

\section{INTRODUCTION}

$\mathbf{T}$ he accurate assessment of voluntary food intake is an important factor in the use of computer models to predict pig growth and carcass composition. The relationship = digestible energy $(\mathrm{DE})$ intake $(\mathrm{MJ} /$ day $)$ $=2.62 \mathrm{M}^{0.63}$ was suggested by ARC (1981) but the Working Party on 'Nutrient Allowances for Growing Pigs' (Stranks, Cooke, Fairbairn, Fowler, Kirby, McCracken, Morgan, Palmer and Peers, 1988) drew attention to the fact that intakes under commercial conditions are frequently lower than this. The results shown below summarize the variations in food intake observed at the Northern Ireland Pig Testing Station, Antrim, during the period 1984 to 1988.

\section{MATERIAL AND METHODS}

For performance testing normally two boars and two gilts per litter were obtained at approximately $25 \mathrm{~kg}$.

\section{TABLE 1}

Composition $(\mathrm{g} / \mathrm{kg}$ ) and analysis (per $\mathrm{kg}$ dry matter) of diet 1 used from 1984 to February 1986 and of diet 2 used from February 1986 to date

$\begin{array}{lcc} & \text { Diet } 1 & \text { Diet } 2 \\ \text { Barley meal } & 503 & 300 \\ \text { Wheat } & 250 & 400 \\ \text { Fish meal } & 60 & 60 \\ \text { Soya } 50 & 125 & 180 \\ \text { Molasses } & 49 \cdot 5 & 49 \cdot 5 \\ \text { Dicalcium phosphate } & 10 & 8 \\ \text { Trace minerals/vitamins } & 2 \cdot 5 & 2 \cdot 5 \\ \text { Crude protein }(\mathrm{g} / \mathrm{kg}) & 210 & 240 \\ \text { Lysine }(\mathrm{g} / \mathrm{kg}) & 10 \cdot 0 & 12 \cdot 0 \\ \text { Digestible energy }(\mathrm{MJ} / \mathrm{kg}) & 15 \cdot 4 & 15 \cdot 3\end{array}$

The boars were housed singly and the gilts as a pair in solid floored pens bedded with shavings. Room temperature was $18^{\circ} \mathrm{C}$ and relative humidity $0 \cdot 70$. Pigs were offered a pelleted diet once daily to appetite, i.e. so that food refusals were minimal, with food offered being increased by $100 \mathrm{~g}$ every 3 or 4 days for singly penned animals and more often for pairs. From 1984 to February 1986, diet 1 (Table 1) was used and subsequent to this, diet 2. Pigs were started on test at $33 \mathrm{~kg}$ and initially offered $1.6 \mathrm{~kg} / \mathrm{day}$. Gilts were slaughtered at $88 \mathrm{~kg}$ and boars were taken off test at $90 \mathrm{~kg}$.

\section{RESULTS}

The mean daily intake of 427 boars ( $\mathrm{kg} /$ day) during 1985 was 2.44 and during $1986 / 88$ the value for 872 boars was $2 \cdot 20$. Figure 1 shows that there was a similar distribution of intakes during the two periods with the decreased intake being uniform over the total population. A comparison of the two periods based on boars from the same sire lines yielded similar results and the difference between the mean values $(2.42$ and 2.22 respectively) was highly significant. In terms of $\mathrm{DE}$ the intakes were approximately 32.6 and $29.1 \mathrm{MJ} /$ day which correspond to 2.43 and $2.17 \mathrm{MJ} / \mathrm{kg} \mathrm{M}^{0.63}$. During the corresponding periods the mean daily intakes of the gilts were $2 \cdot 40$ and $2 \cdot 20$ respectively.

\section{DISCUSSION}

The DE intakes per $\mathrm{kg} \mathrm{M}^{0.63}$ recorded during 1985 (diet 1) are similar to those reported by Patterson (1985) with individually housed commercial-quality pigs fed $a d$ libitum on pelleted diets of similar nutrient content. So far as can be determined there was no change in feeding 
management associated with the diet change in 1986. However, there was a dramatic drop in intake, which, taken in conjunction with the information for the smaller sample of same sire lines suggests that the reduction in intake was directly attributable to the higher protein content of the diet. The net effect was for total crude protein intake to remain similar to that which had occurred with diet 1 . The similarity of intake of boars and gilts is in agreement with Patterson (1985) and many previous observations (ARC, 1981).

The wide individual variation in intake is worthy of comment. During 1985, the average daily intakes of boars ranged from 1.79 to $3.13 \mathrm{~kg}$ with $74 \%$ lying between 2.2 and $2.6 \mathrm{~kg}$. During 1986/88 the range was 1.56 to 2.76 with a similar proportion lying between 2.0 and $2 \cdot 4 \mathrm{~kg}$.

\section{CONCLUSIONS}

It is concluded that the DE intake of fattening pigs is likely to be considerably lower than the value recom- mended by ARC (1981). It would appear that increasing the dietary protein content may reduce voluntary food intake. This could be an effective management tool to obtain satisfactory grading under conditions of ad libitum feeding.

\section{REFERENCES}

Agricultural Research Council. 1981 The Nutrient Requirements of Pigs. Commonwealth Agricultural Bureaux, Slough.

Patterson, D. C. 1985. The effect of nutrient density of the diet and of a change in nutrient density on the performance of pigs fed ad libitum for bacon. Animal Production 40: 169-174.

Stranks, M. H., Cooke, B. C., Fairbairn, C. B., Fowler, N. G., Kirby, P. S., McCracken, K. J., Morgan, C. A., Palmer, F. G. and Peers, D. G. 1988. Nutrient allowances for growing pigs. Research and Development in Agriculture 5:

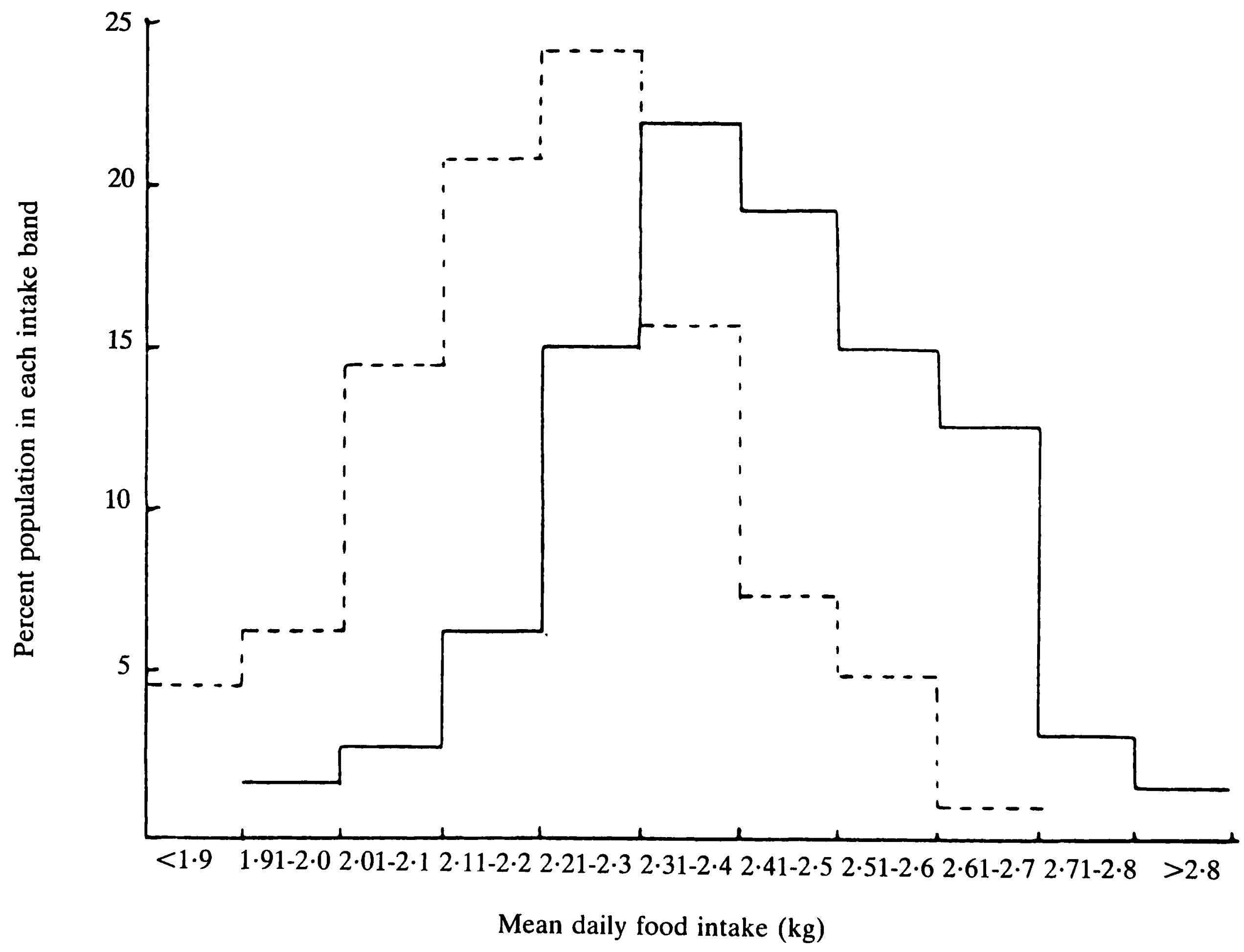

FIG. 1. Distribution of food intake (kg/day) for pigs given diet $1(-)$ or $\operatorname{diet} 2(--)$. 